\title{
Healing history, healing a nation: A prophetic practical pastoral ministry of care
}

\begin{tabular}{|c|c|}
\hline $\begin{array}{l}\text { Authors: } \\
\text { Mabutho Mka } \\
\text { Yolanda Dreye }\end{array}$ & $\begin{array}{l}\text { ndla }{ }^{1} \text { (D) } \\
r^{1} \text { (D) }\end{array}$ \\
\hline $\begin{array}{l}\text { Affiliations: } \\
\text { 'Department } \\
\text { Theology, Fac } \\
\text { and Religion, } \\
\text { of Pretoria, Pr } \\
\text { South Africa }\end{array}$ & $\begin{array}{l}\text { ractical } \\
\text { Alty of Theology } \\
\text { Jniversity } \\
\text { etoria, }\end{array}$ \\
\hline $\begin{array}{l}\text { Research Proj } \\
\text { Project Leade } \\
\text { Project Numb }\end{array}$ & $\begin{array}{l}\text { ct Registration: } \\
\text { r: Y. Dreyer } \\
\text { er: } 2546930\end{array}$ \\
\hline $\begin{array}{l}\text { Description: } \\
\text { This research } \\
\text { project, 'Gend } \\
\text { Practical Theo } \\
\text { Formation', di } \\
\text { Prof. Dr Yolan } \\
\text { Department o } \\
\text { Theology, Fac } \\
\text { and Religion, } \\
\text { of Pretoria. }\end{array}$ & $\begin{array}{l}\text { s part of the } \\
\text { er Studies and } \\
\text { logy Theory } \\
\text { ected by } \\
\text { Ja Dreyer, } \\
\text { f Practical } \\
\text { llty of Theology } \\
\text { Jniversity }\end{array}$ \\
\hline $\begin{array}{l}\text { Correspondin } \\
\text { Yolanda Dreye } \\
\text { yolanda.dreye }\end{array}$ & $\begin{array}{l}\text { g author: } \\
\text { r, } \\
\text { r@up.ac.za }\end{array}$ \\
\hline $\begin{array}{l}\text { Dates: } \\
\text { Received: } 04 \text { J } \\
\text { Accepted: } 18 \\
\text { Published: } 23\end{array}$ & $\begin{array}{l}\text { une } 2019 \\
\text { Aec. } 2019 \\
\text { Apr. } 2020\end{array}$ \\
\hline $\begin{array}{l}\text { How to cite th } \\
\text { Mkandla, M. \& } \\
\text { 2020, 'Healing } \\
\text { healing a nati } \\
\text { practical pastc } \\
\text { care', HTS Teo } \\
\text { Theological St } \\
\text { a5597. https:/ } \\
\text { 10.4102/hts.V }\end{array}$ & $\begin{array}{l}\text { is article: } \\
\text { Dreyer, Y., } \\
\text { history, } \\
\text { n: A prophetic } \\
\text { ral ministry of } \\
\text { ogiese Studies/ } \\
\text { idies } 76(1) \text {, } \\
\text { /doi.org/ } \\
76 i 1.5597\end{array}$ \\
\hline $\begin{array}{l}\text { Copyright: } \\
\text { (c) 2020. The } A \\
\text { Licensee: AOS } \\
\text { is licensed un } \\
\text { Creative Comr } \\
\text { Attribution Lic }\end{array}$ & $\begin{array}{l}\text { uthors. } \\
\text { S. This work } \\
\text { ler the } \\
\text { nons } \\
\text { ense. }\end{array}$ \\
\hline Read online & \\
\hline 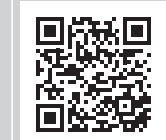 & $\begin{array}{l}\text { Scan this QR } \\
\text { code with your } \\
\text { smart phone or } \\
\text { mobile device } \\
\text { to read online. }\end{array}$ \\
\hline
\end{tabular}

Authors:

Affiliations:

${ }^{1}$ Department Practical , Faculty of Theology

South Africa

Research Project Registration: Project Leader: Y. Dreyer Project Number: 2546930

Description: project, 'Gender Studies and Practical Theology Theory Formation', directed by Department of Practical Theology, Faculty of Theology and Religion, University

Corresponding author: Yolanda Dreyer,

dreyer@up.ac.za

How to cite this article:

healing a nation: A prophetic practical pastoral ministry of Theological Studies $76(1)$ a5597. https://doi.org/

Licensee: AOSIS. This work

is licensed under the

Creative Commons

to read online.
In the late 19th century, colonial powers sought to destroy the Mthwakazi or Ndebele state in what is now Matabeleland in the south west region of Zimbabwe, to subdue and dominate its people. The people of Matabeleland suffered heavy losses of cattle and land. Paradoxically, these injustices did not end with the collapse of colonialism. Since independence in 1980, the people of Matabeleland have been victims of political violence, which has left thousands dead and many without a livelihood. Nothing came of the promised reconciliation, justice, peace, national cohesion, progress and prosperity in the post-colonial Zimbabwe. To date the region of Matabeleland still suffers from political, cultural and socio-economic disadvantages that call for a prophetic practical pastoral ministry of care. A critical exploration of the way in which the history of the region was documented exposes it as a victim of the legacy of injustice and political violence. This has had the effect of undermining progress and peace not only in Matabeleland, but also in the entire country. There is a lack of national cohesion, and the consequence is the absence of a common national vision. Notwithstanding the general prevalence of political and socio-economic dire straits affecting the whole country, Matabeleland presents a unique case study. The Roman Catholic Church which has been present in the country since colonial times has been actively engaged in the political and socio-economic realities of the country. In view of this, this article investigates the role the Church can play in the healing of a broken nation, with a preferential focus on Matabeleland. It proposes a prophetic practical pastoral ministry of care in order not only to heal the afflicted but also that they may find solidarity and fellowship as citizens. Such a role should further encompass reconciliation, rebuilding the people's confidence and advocacy for their political, cultural and socio-economic development and progress.

Keywords: practical theology; pastoral ministry of care; social challenges; Zimbabwean history; Roman Catholic Church.

\section{Background}

Before delving into the subject matter, 'healing history, healing a nation', the article proposes its contextualisation by providing the background. At the dawn of a newly independent Zimbabwe, there was a sense of optimism, 'a deep sense of what the country stands for: liberation, majority rule, democracy and human rights' (Meldrum 2004:17). These ideals were against the background that this nascent state was emerging from a prolonged struggle for independence which was characterised by conflict and division. Amongst the ordinary citizens who had borne the brunt of a terrible war, the fatigue caused by the episode of that violence was clearly visible. As if to fulfil people's aspiration for reconciliation and peace, the newly elected government announced a policy of reconciliation which 'clearly embodied this delicate task of nation-building' (Raftopoulos 2004:x). Fundamentally, the requirement was for mechanisms to amicably manage this new political order to eclipse the legacy of injustice. Therefore, there was a need for reconciliation if there could be any meaningful optimism for a smooth transition to a new dispensation of justice and peace in the newly independent Zimbabwe. Hence, the announcement of the policy of reconciliation by the new government coincided well with people's aspirations weary of the devastating effects of war and violence. In the words of the South African theologian Villa-Vicencio (2004:v), the new government 'promised a move beyond the kind of coercive rule entrenched by colonialism and Ian Smith's minority regime'. A new dispensation was anticipated and the mood in the country generally was euphoric. However, the question was, 'how long would this mood of joy and happiness prevail, as there were no visible and tangible signs to resolve the differences that bedevilled major political parties?'.

Despite the apparent exhilaration of ordinary citizens, a cloud of uncertainty hung over this incipient state because of the legacy of historical conflicts. Ironically, the 1980 elections were significantly unable to usher in a meaningful democracy and a new beginning, but rather reflected 
that the birth of the new nation would still bear the legacy of violence that had been the hallmark of the war of liberation. The outcome of a first democratic election was indeed less than optimistic. The country had practically split into two competing regions based on ethnicity and the insatiable quest for political power and dominance. Joshua Nkomo (1984:211) had observed the fragile nature of things after the divisive outcome of the first elections and warned that ' $[a]$ ny bickering now would inflame passions, divide the people and encourage the enemies on our borders to destabilise the country'. Hence, in the early years of independence and apparently because of ineptitude and lack of political will by the post-colonial ruling party, political violence ensued and this sealed the fate of the new country. In Bhandar's (2007:95) words, it did not succeed in "'settling" the past' and 'move towards a post-colonial conflict, post-colonial state of being'. The volatile political climate was exacerbated by the so-called dissidents that roamed the country. In responding to the situation, the post-colonial ruling party chose to emphasise and concentrate on Matabeleland and parts of Midlands. This further fractured the country along regional and ethnic lines. The dissidents in Matabeleland were naturally aligned to the ex-ZIPRA and ZAPU and as such raised an alarm on state security, 'a source of destabilization because the apartheid regime sought to fan the conflict' (Sachikonye 2011:15). However, the reaction of the state turned out to be directed towards unarmed ordinary people. It unleashed a specially trained 5 Brigade known for its notoriety as the Gukurahundi on civilians accusing them of supporting or working in cahoots with dissident elements. 'It seemed that state armed forces - whether only 5 Brigade or others too had gone berserk in an orgy of violence against defenceless civilians' (Todd 2007:49). These events taking place immediately after the country's attainment of the majority rule had repercussions on the country's young democracy; it could not be consolidated by the disproportionate use of force even against affirmed state enemies. More worrisome was the brigade's overtly ethicised and politicised overtones in its methods. According to Meredith (2002:67), '[v]illagers were forced to sing songs in the Shona language praising Zanu-PF while dancing on the mass graves of their families and fellow villagers'. This would have serious ethnic and political ramifications of an atmosphere of bitterness and distrust of the majority rule that was rather manifesting itself more as 'majority Shona rule'. Hence, Raftopoulos (2004:6) regards the coalition government that had been formed at independence as a 'veneer of national unity', which 'was soon torn asunder in the crisis that developed in Matabeleland and the Midlands in the mid-1980s'. Democracy and human rights had been stifled more than ever in the modern history of the country. The independence euphoria that was nothing short of phenomenal had vanished and one-third of the country had been plunged into sorrow and mourning. Diat (2015) argues that:

$[T]$ rue democracy cannot be the arbitrary rule of the majority. For is the majority necessarily just? Obviously the answer is no. Sometimes the minorities are the ones who hold the truth ... (p. 180)
Thus, the post-colonial regime started on a false and sad note by adopting the same methods of cruelty as that of its predecessor white minority regime. There were serious implications on the task of nation-building, and subsequently nationhood. For the people of Matabeleland, especially of the Ndebele-speaking stalk, the pomp apparently signifying a new beginning was nothing but façade as political violence escalated beyond anything they had experienced during the war of liberation. The country was moving apart at an age that could be least expected. Lubich (1985) perceives that:

$[A] \mathrm{s}$ we approach the third millennium after Christ, there is a sense that the human family is about to start a new phase in its history - but not necessarily of yet another deep-rooted division, rather of a movement towards a new unity of the human family. (p. 7)

Contrary to this perception, the new Zimbabwe was more determined in encouraging the divisions and conflicts that had characterised its war era. In a particular way, the people of Matabeleland were deeply hurt. Thus, the failure to settle the conflicts of the past had catastrophic results of political, cultural and socio-economic consequences. This article aims to investigate the possibility of the Roman Catholic Church's role in bringing about reconciliation, healing, justice and peace.

\section{Settling history}

The background reflects Zimbabwe as a country with a historical legacy of violence and suffering. An election that brought the country's independence had been less satisfactory, but the results could not be annulled (Nkomo 2013:201). There were 'negative elements in the campaign threats of death, murder or abduction of candidates and agents, destruction of property, among other violations' (Nkomo 2013:200).

This left unattended set a wrong precedence for all elections to come; the legacy of violence was to remain; history remained unchanged. In the context of that, the people of Matabeleland uniquely share the pain and suffering from a part of that legacy, a legacy that has excluded them from political, cultural and socio-economic development. With hindsight to such a painful history in Zimbabwe, with special focus on the south western region of Matabeleland, it needs a redress to overthrow its debilitating effects. Such a history provides an excuse for failure (Guest 2004:10). Nkomo (1984) declares:

$[I]$ refuse to accept that we cannot do better than we have so far done, or to reach for an easy excuse that all our mistakes are simply colonial inheritance that can conveniently be blamed on the invaders. (p. 245)

This declaration is what Zimbabweans need to make collectively and individually because the challenge is blaming everything on the defunct colonialism. In a similar way, the people of Matabeleland need to debunk from negativity and begin to assert themselves and focus on harnessing their potential for development and progress. History can be a problem that holds people into hostage of 
their past, as Guest (2004:8) claims that the 'popular culprit for Africa's ills is history'. When a country's history is littered with negativity and is not accepted by all, it creates misunderstanding. Nkomo (1984:228) admits that 'even our [Zimbabwe] national history is distorted'. In many respects, people can conveniently point to the past for their failure in making progress in life. According to Guest (2004:11), the 'problem with blaming the legacy of colonialism for Africa's current woes is that it gives little clue as to how these woes could be ended'. In this case, 'substitute' Zimbabwe for Africa, the country has gotten into the habit of passing the bark for its political and socio-economic woes to its former colonial master, Britain and her western allies. In fact, against this mentality, Nkomo (1984:245) says 'it is up to us to do better now'. The point is not to allow history to negatively determine the present and the future, thus, of course, without undermining its importance. Bernier (2015:xviii) asserts that 'being grounded in history gives us hope of remaining in touch with reality'. Of course, this is in reference to pastoral forms that emerge from different epochs of history (Bernier 2015). There is reason to believe that this applies to all forms of history indicating to their indispensability. However, it must always be true, authentic and tested history free of distortions and exaggerations. Indeed, Parker (2001:47) points to the fact that 'issues of unacknowledged history and unhealed memories ... [could be] powerful contributory factors in engendering present day conflicts, prejudices and bitterness'. Nonetheless, there must be ways of dealing with the effects of wounded history to rectify where it can be and forgiven when it cannot be reconciled with the present. In this regard, it is possible to engage in the process of healing history with subsequent healing of a nation (Parker 2001).

The present situation in Zimbabwe has deep historical roots anchored in the pre-colonial and colonial eras.

Thus, the country is encumbered by the baggage of its unresolved historical violence and conflicts between different racial and ethnic groups. Eppel (2004:43) describes Zimbabwe as 'a nation with more than a century of unresolved conflicts ... intentionally exacerbated by colonialism'. The effects of unsettled history are both devastating and persisting. HaroldBarry (2004:256) describes it as follows: '[u]nfortunately, the history of the previous 90 years cast a long shadow on the early 1980s and no one was big enough to free the country from it'. Even with respect to the question of the woes besetting Matabeleland, the Zimbabwe Catholic Bishops' Conference (ZCBC) (2009b) points out:

The Shona have passed on to their children stories about the raids which involved the confiscation of cattle, food, strong young men and beautiful women by the Ndebele. The Shona have, over years, cultivated negative feelings towards Ndebele groups. These feelings include hatred, contempt, suspicion and the desire to retaliate. (p. 3)

It is a history that pre-dates colonialism with its emphasis on the Ndebele-Shona conflicts of the late 19th century. HaroldBarry (2004:256) points out that the Shona 'have memories of
Ndebele pillage of their lands in the years before the settlers came'. This emphasis is against the backdrop that 'it has been established that the extent of the Ndebele raids have [sic] been exaggerated especially by the early missionaries' (Mavuru et al. 2008:65). This is somewhat curious that the horrors of the 90 years of colonial rule failed to expunge that memory. Could it that those memories are but a pure re-construct of the clever minds basing their arguments on the settler colonial regime's narrative bent on perpetuating divisions for its own expediency? Mukonori (2017:234) does not wholly subscribe to the ancient Ndebele-Shona rivalries but is rather 'more inclined to look at recent causes in the changes of society to understand why violence re-emerges'. This script does not attempt to deny pre-colonial rivalry between the two nations' people but is rather wary about what appears as an exaggeration of historical facts.

\section{According to Nkomo (1984):}

Of course, our history has made us what we are, and the recent period of that history was distorted first by the influence of the remote empires, then for ninety years by direct colonial rule. (p. 245)

In this case, there must be a critical reading of history. According to Guest (2004:11), '[ $h$ ]istory, like geography, cannot be changed. Grieving for the past wrongs is natural and human, but it can also provide an excuse for despair'. However, from a theological perspective, 'the event of Christ makes history supremely relevant to salvation. In him, history - his word, his actions, the events of his life - is simultaneously salvation' (The Theological-Historical Commission for the Great Jubilee of the Year 2000, 1997:57). Thus, Jesus incarnate is a 'historical personage' and every practical pastoral theological enterprise hinges on and is rooted in his entire earthly existence which occurred in human history. Therefore, it could be argued from this perspective that while history cannot be changed, it can be saved. The question is whether pre-colonial historical rivalries between the Ndebele and the Shona could justify the actions of the post-colonial ruling party in Matabeleland in the early to late 1980s? The region was subjugated with violence and subsequently marginalised on the political, cultural and socio-economic fronts. It boggles the mind that the ills of ancient history can, in the present age of enlightenment, democracy, constitutionalism, freedom, respect for human dignity and rights, be allowed to replay itself. According to Godwin (2006:22), the 'sheer scale and ferocity of the killings dwarfed anything that had happened in the independence war'. If pre-colonial rivalry between the Ndebele and the Shona accounts for these 'killings', then certainly that history needs serious scrutiny.

According to Nkomo (1984:212), the newly elected black government of 1980 'did make an attempt to reconcile the nation to itself'. The hope and optimism at independence lasted for several years (see Meredith 2005:619). Coltart (2016:111) points out that 'Mugabe's first acts in office were constructive and designed to consolidate the peace'. These efforts soon dissipated. There was a growing concern that the 
nascent state was grappling with a potentially explosive situation, particularly in Matabeleland and parts of Midlands where the state was dealing with what it called 'insurgency'. The ministry of defence categorically stated 'that 5 Brigade was going to operate in Matabeleland for a long time' (Todd 2007:49), curious enough, not as long as the problem of the so-called dissidents persisted. An entire army brigade was pursuing the so-called dissidents 'a numerically small force. It was estimated that there were probably no more [than] 500 dissident fighters at the height of the conflict' (Sachikonye 2011:15).

Written narratives sometimes cannot be trusted. Claims such as that over 3000 dissidents combatants were killed, would be dispute by any resident in Matabeleland. There were never serious incursions between the so-called dissidents and the 5th Brigade that could account for such a number. The bandits were a loose group without any adequate arms, let alone any sophisticated weaponry. They did not have any central command nor did they show any organisational form or structure of a fighting force. On the contrary, they went about doing the same things as the 5 Brigade though at a very marginal scale. Anything opposed to these facts suggests distorted narrative that needs serious scrutiny. Nonetheless, the truth of the matter is that the people of Matabeleland have remained under oppression for quite a considerable time even in a free Zimbabwe. Nkomo (1984:245) laments, ' $[t]$ he hardest lesson of my life has come to me late. It is that a nation can win freedom without its people becoming free'.

Although these words have become prophetic for the whole of Zimbabwe today, they primarily applied to the situation of Matabeleland and part of Midlands at the time they were uttered. It was now the majority rule that was intolerant and scared of the minority groups and their opposition. The majority ethnic group assumed a new status that resembles a form of 'internal colonialism' (Mabhena 2014). How applicable could these words be in a context such as this (Diat 2015):

[T] his form of government is not exactly majority rule, but approximates it. Does a majority still deserve the name when it crushes racial, religious, and political minorities with the help of oppressive laws? (p. 179)

In a way, it was a replication of the oppressive system that characterised the Zimbabwean political landscape under the colonial regime. This had serious political, cultural and socioeconomic repercussions in Matabeleland. There are human rights abuses, sporadic outbreaks of political violence and an ongoing socio-economic crisis. These are the realities of this independent, democratic country. What has been and, to a lesser extent, still happening is because independence is attributed to unresolved differences and conflicts that preceded independence. Mutanda (1984:xi) describes the population as 'a divided, confused and frightened people, led by a divided, confused and frightened government'. Therefore, the need for healing history with culmination of healing a nation is most appropriate and relevant if reconciliation, justice and peace are to be achieved. According to Nkomo (1984):
[I]n the old, pre-colonial days the territories of each of the peoples in the land were defined only by custom: their vagueness led raids and counter-raids in search of cattle, food or women. Now there was no reason why all of us should not unite and develop an unquestioned sense of national identity. (p. 7)

Therefore, the pre-colonial era rivalries could not be reasonably used to determine people's present relationships because of their 'vagueness'. There should not even be an oversight that the benefit of the colonial government 'was that it defined, once for all, our national borders' (Nkomo 1984:7).

Within 'our national borders', Zimbabweans are one and there is greatness in unity. The ZCBC (2011:3) warns that 'the evolving trends in our country are worrying and, if not corrected, can lead to our loss of nationhood, the disintegration of our society ...'. Although this is in reference to the broader context of the country, it is not irrelevant to the scenario in Matabeleland. The legacy of regional divisions and conflicts needs healing and this will eventually heal the nation. The Church's prophetic practical pastoral ministry of care can play a pivotal role in these pertinent processes. According to Diat (2015:188), the Church 'is in favour of progress if it promotes the real good of mankind [sic] ...' This recognition and acknowledgement of the church's role with regard to the social issues of injustice motivates this investigation that proposes a practical theological approach for solutions.

\section{A practical pastoral response}

The context explored above challenges methods of approach that could ameliorate the situation. While there can be various approaches to this scenario, this article proposes a practical theological dimension. In essence, it is the application of a prophetic practical pastoral ministry of care as a response that is postulated. This approach is rooted and embodied in the common and broader traditional notion of pastoral care. 'Pastoral care derives from the biblical image of shepherd and refers to solicitous concern expressed within the religious community for persons in trouble or distressed' (Oates 2007:836). However, the scope of this article transcends beyond this and reaches out to the communities in general. Thus, from this sense, pastoral is taken in a broader sense of caring extending beyond faith community borders. The emphasis then is the ministry of caring within the broader context of evangelisation. It is a ministry of caring that is the responsibility of all Christian believers, the Church leadership and the lay faithful (Francis 2013a):

It is not the task of the Pope to offer a detailed and complete analysis of contemporary reality, but I do exhort all the communities to an 'ever watchful scrutiny of the signs of the times'. (p. 51)

Prophetic practical pastoral ministry of care, nonetheless, does not constitute the invention of new phraseology. Rather, it serves to stress the uniqueness of the context under review and the emphasis on the nature of pastoral ministry as an embodiment of caring not just for souls within a community 
of believers. It is a ministry of care for all and carried out by all and inspired by the gospel which 'sides with freedom against the forces of oppression. Hence the new consciousness we have today about the necessary link between social justice and the proclamation of the gospel' (Bernier 2015:xviii). In fact, in practice, through social programmes whether they are charity work or developmental projects and advocacy for particular needs, the Church is already carrying out the ministry of care. Wolfteich (2014:12) makes an undisputable claim that ' $[p]$ ractical theology lives in Catholic social teaching, which ... has brought a critical faith perspective to contemporary economic, political, social, and cultural issues'. This constitutes the practical dimension of the Church's pastoral ministry of care beyond itself. It is critical to view this mission ad extra as embodied in the commissioning of the apostles as attested in the Gospel of Matthew: 'Go, therefore, and make disciples of all nations, baptizing them in the name of the Father, and of the Son, and of the Holy Spirit, teaching them to observe all that I commanded you' (Mt 28:19-20). More than this is the prophetic nature of this mission:

$[T]$ o bring glad tidings to the poor ... to proclaim liberty to captives and recovery of sight to the blind, to let the oppressed go free, and to proclaim a year acceptable to the Lord. (Lk 4:18-19)

If Francis' (2013:51) words could be applied, ' $[t]$ his is in fact a grave responsibility, since certain present realities, unless effectively dealt with, are capable of setting off processes of dehumanization which could be hard to reverse'. The implication of these texts reaches out to the world through a ministry of care attuned to the practical environment of the recipients. Therefore, the object of this article is to link this practical pastoral practice within the situation of Zimbabwe with preferential option for Matabeleland.

\section{Solidarity with the victims of political violence}

The pastoral document of the Church, Gaudium et spes (1966), clearly states:

[T] he joy and hope, the sorrow and anxiety of men [sic] of our time, especially of the poor and of those who are in any way suffering; these Christ's disciples make their own, and there is nothing human that does not find an echo in their hearts. (p. 1)

Guided by the spirit and the pastoral demands made in this document, the Church everywhere seeks solidarity with humans and their conditions. The church in general throughout the history of Zimbabwe has played a significant role, and continues to do so today. During the colonial era, it stood with the ordinary people suffering colonial injustices. Maye (2010:32) attests to this claim by acknowledging that 'the churches in Rhodesia had established and coordinated a programme to relieve the hardships people in these villages were suffering'. The conditions created by the settler colonial rule subjected ordinary black people to servitude. This called for a prophetic practical pastoral ministry of care from the church leadership and its faith communities. Nkomo (1984:236) affirms that the Roman Catholic Church 'had bravely spoken out against the crimes committed by the forces of the Smith regime'. Thus, in the context of the war of liberation, the Church dared stay close to the people in the practical reality of their difficult situation. The prodigious role of the Church was carried mostly by white missionaries who at the time dominated the Church leadership. Through this leadership, in a way, the church was part of the black majority's struggle against white racist regime of Ian Smith. It pursued the cause of justice and criticised the white rule when it was most unfashionable to do so. The Roman Catholic Justice and Peace (RJCP) then, now the CCJP, responded to the humanitarian situation in the country created by the sanctions placed against the minority regime. Bishop of Gweru, Alois Haene, who was the president of the commission, sought help from Trocaire in Ireland. He wrote (Maye 2010):

Our position is such in Rhodesia that due to sanctions, political tensions and fear of losing one's privileges, the white population is not prepared to support financially or otherwise a commission whose aims are to bring about social justice. (p. 31)

The struggle for social justice has always been the distinctive character of the Roman Catholic Church within Zimbabwe's polity. It refuses to remain untouched by the plight of the people. So, during the liberation struggle, it participated in the emancipation of the black majority. Even then, it became aware that even among the different nationalist movements, there were unsavoury events of divisions and conflicts. Those differences were not resolved, let alone reconciled up to the time of independence.

Therefore, the task of the Church became even more urgent in the early years of post-colonial era. Remaining in the middle of that war of liberation meant the Church had to stay on the side of the ordinary citizens often caught in suffering and pain caused by that war. According to Karlen (1990), ' $[b]$ y defending the beaten up and crushed population and by standing up against injustice and violation of human rights the credibility of the Church was greatly enhanced'. Notwithstanding this noble and exalted role, the Church paid a high price of sacrifice. Karlen (1990:2) admits the difficulties in these words, 'we learnt to believe in the theology of the dying grain and that gave us strength to start anew and carry on'. Many missionaries were killed and missions were destroyed but the Church held on.

At the close of the war of liberation, the Church took on the practical task of caring for the returnee refugees.

The then Catholic Commission for Social Services and Development (CSSD) played a pivotal role in the aftermath of that war. For instance (Todd 2007):

[F]ather Thomas Peeters, head of CSSD in Bulawayo, was heavily involved in caring for the returned refugees, such as the hundreds of children who had been under the care of 
Zapu in Zambia and had since been handed over to the good offices of the Catholic Church in Matabeleland. (p. 41)

This reiterates the Church's commitment to a practical pastoral ministry of care. Its aid was truly visible as a clear testimony of its faith in the true value and dignity of humanity. On the occasion of the inauguration of a newly elected government after the independence of 1980, it was a Catholic Archbishop of Harare, Patrick Chakaipa, who presided over the religious ceremony performed therein. The inauguration ceremony was held amidst pomp and excitement, signalling the end of colonialism and the advent of a new dispensation that would debunk colonial excesses of injustice. However, it was not long before the realisation of a looming danger. Behind the euphoria of independence loomed a dark cloud that would soon manifest divisions that had characterised the liberation struggle. Hence, Meldrum (2004:50) reveals that 'although trouble was brewing in Matabeleland, the arid southern region where most of the country's Ndebele people lived, life continued as normal in Harare'. Against the backdrop of the euphoria of independence, the enunciated policy of reconciliation was not holding its centre; it was crumbling without takers.

The Catholic bishops were following uncanny political developments with keen interest. Diat (2015) is:

[C]onvinced that a democracy that contributes to the integral development of mankind [sic] cannot continue without God ... always the eclipse of what is divine means the debasement of what is human. (p. 180)

By all indications, the nascent state was quickly sliding into the abyss human degradation of inequality and subjugation. According to Meldrum (2004:62), '[t]he mood of the country was deeply divided' and it was apparently clear that political tension was increasing. This was deeply felt in Matabeleland only while 'throughout Mashonaland many people were still praising the Mugabe government for bringing independence to the nation' (Meldrum 2004:62). Naturally, such developments were divisive and threatened the country's peace and stability not to speak of national cohesion. As early as 1982, the Catholic bishops released a statement to the effect that the government's ' $r$ ]esponsibility is to foster ... unity and reconciliation ... directives and public announcements should [aim] to this end, and anything which provokes and inflames past hatreds should be avoided' (Roman Catholic Bishops of Zimbabwe 1982:4-5). The statement clearly indicates that the bishops were aware of the past conflicts that needed not to be 'provoked'.

Apparently, the government did not heed this call as the situation was fast deteriorating unabatedly. In what appeared as counter-insurgency, the post-colonial government deployed the 5 Brigade army code named Gukurahundi in Matabeleland and parts of Midlands, which carried out disproportionate forms of violence, killings and rape against unarmed civilians. Ordinary people were subjugated with terror and their homesteads were burnt down and their livestock were slaughtered 'simply to instil fear' (Nkomo 1984:235). These unsavoury incidences alarmed the Roman Catholic Church and Bishop Karlen sought to meet the country's leadership (Todd 2007). According to the CCJP \& LRF 1997, the Church's representatives consisting of two bishops and the chairperson the CCJP presented their reports on the atrocities to the then Prime Minister, Robert Mugabe. They presented the report containing damning evidence of the 5 Brigade atrocities, which also included a statement by the ZCBC entitled 'Reconciliation is Still Possible'. However, the leadership of a newly independent country refused to listen. On the contrary, the government was angered by the Church's actions. According to Meredith (2002), the authorities issued a warning against the Church's role:

The Church of Zimbabwe, whatever denomination, must abandon forever the tendency or temptation to play marionette for foreign so-called parent churches whose interest and perspective may, and often will be, at variance with the best interest of the people of our country. (p. 68)

It became clear that the new post-colonial regime was set on a course of destruction for a cause and expediency interpreted as both ethnic and political. Even in the context of this warning, the Church did not relent but kept pressure on the government. While the post-colonial government 'poured scorn on the report[s]' by Catholic bishops, Joshua Nkomo 'declared that [he] knew the reports of atrocities were true' (Nkomo 1984:243). This leaned truth to the statement that '[i]nstead of slowly withering away or lodging itself quietly into the privacy of worshipers' hearts it has emerged as an important player on the national and international scenes' (Volf 2001:27). The Church remained focused and committed to ensuing peace in the affected regions. Its personnel in the rural missions continued to play a significant role, providing refuge to the hapless victims of political violence of aggravated nature (Meldrum 2004:56). It was the ordinary Catholics and staff in various missions scattered throughout the region who 'had been assembling evidence from their network of churches, schools and hospitals throughout the rural areas' (Meldrum 2007:49). This evidence they handed over to the Church's authorities to vindicate claims of disproportionate forms of violence and abuse against civilians. The work encompassed all structures of the Church: bishops, priests, religious sisters, lay pastoral workers, and mission staffs both in schools and hospitals.

In the worst circumstances where people had been beaten, injured and left for dead by the 5 Brigade, some mission hospital workers dared to go to collect the victims and brought them for treatment. Doctor Johanna F. Davis provides an important example of practical pastoral ministry of care. She tells her story (Davis 2013):

In the afternoon I went by ambulance with one of our workers to Silwane, to collect those who had been injured and who were unable to walk. I proceeded from village to village and found each place one or two dead. (p. 62) 
Such first-hand experience provided irrefutable evidence that, indeed, atrocities were being committed and also that the Church was close to the victims in the most realistic manner possible. Hence, 'reports of fresh murders in Matabeleland came in from other church and medical sources' (Meldrum 2004:59). Such evidence coming from witnesses who were not only observers but also actually involved in trying to save the lives of the victims revealed the true nature of things. Nkomo (1984:236) testifies to the work of priests when he says, ' $[a]$ s impartial witnesses I can quote the priests of the Roman Catholic church in Matabeleland. Their church is not a dissident organisation'. Their reports served as a basis for CCJP to lodge appeals to Mugabe (Alexander 2000:219; CCJP \& LRF 1997:53). All these admit to the fact of the practical role of the church played at the time. According to Todd (2007:49), bishop Henry Karlen risked his life when he planned to meet the then Prime Minister Robert Mugabe 'to tell him what was happening and to get him to stop it'.

However, the leadership did not take the bishop's genuine concern in kindness but rather issued a vitriolic attack on him. Therefore, ' $[w]$ hen [Karlen] charged the government with employing a policy of systematic starvation, Mugabe retorted that he was more interested in worshipping Nkomo than God' (Meredith 2002:70). The Catholic bishops in a clear sign of solidarity reiterated and supported their own confrere by issuing pastoral statements confirming the facts of Karlen's concerns. However, the government reacted and [d] escribed the Catholic bishops' statement as 'irresponsible, contrived propaganda' [and the] prime minister said the bishops were 'mere megaphone agents of their external manipulative masters'; he called them 'a band of Jeremiahs' (Nkomo 1984:237). Nevertheless, these attacks on the bishops did not diminish the role of the Church and it had an important influence on the international community. Hence, it was not surprising that the City Council of Bulawayo in 2007 granted bishop Karlen a prestigious Civic Honour for 'expos [sing] the massacres of 20000 civilians [and] helping victims of the government's military campaign' (The Zimbabwean, 6-12/12/2007). In the same manner, The Zimbabwean, an independent newspaper, gave credit to both former bishops of Bulawayo, Karlen and Pius Ncube, 'for bringing the killings to the attention of the international community'. The timing of bestowing the prestigious Civic Honour was also curious because Archbishop Pius Ncube, a fierce critic of the post-colonial government, had resigned under what was apparently a scandal. All indications pointed to the plot and role of the government determined to silence him. Nevertheless, the role of the Church was incontrovertible and esteemed. The cessation of the killings was partly and significantly attributed to it. Thus, the exposure became as it were a facilitator to the dialogue between PF-ZAPU and ZANU-PF for unity.

\section{The failure of the Unity Accord}

The reign of terror finally ended with the signing of the Unity Accord in 1987 between PF-ZAPU and ZANU-PF after long talks. 'To avoid further violence and repression, Nkomo capitulated' (Meredith 2002:72). With this, the unity achieved did not come on a genuine clean slate but as both a sacrifice and compromise (Manyika 2006:153). Against all odds, Joshua Nkomo was more determined because his 'own interest in unity is that if it materialises it will bring the people of this country together' (Nkomo 2013:15).

Fundamentally, the unity was viewed as a panacea not only to the political conflict but also to the socio-economic woes of Matabeleland. Meldrum (2004:65) testifies that 'it was hard to reconcile the horrors perpetrated on the people of Matabeleland with positive developments in health and education throughout the rest of the country'. The people of Matabeleland deeply felt deliberate rejection and exclusion, hence marginalisation. According to Mabhena (2014):

[T]he state went through the motions of development in a very uncommitted fashion and tended to be satisfied that it had achieved its objectives as long as necessary political structures and controls had been put in place. (p. 14)

This has been largely viewed as a strategy to police the region and undermine its development potential. The region of Matabeleland is rich in natural resources and yet the locals do not benefit from these resources. On the employment level, the importation of labour from the eastern regions is itself a testimony to the deliberate plan to alienate and deny the Matabeleland people opportunities of improving their own standards of life. Francis (2013:53) rejects 'an economy of exclusion' and says that just as the commandment 'Thou shalt not kill' sets clear limit in order to safeguard the value of human life, today we also have to say 'thou shalt not' to an economy of exclusion and inequality. Fundamentally, the yawning gap of political, cultural and socio-economic development between Matabeleland and Mashonaland needed urgent redress in order to expedite national healing, reconciliation, peace and cohesion. Yet, on the contrary, reality reflects that ' $[i] \mathrm{n}$ practice, we continue to tolerate that some consider themselves more human than others, as if they had been with greater rights' (Francis 2015:90).

In such circumstances, there is an irreconcilable chasm between peoples, and in the context of Zimbabwe, this requires commitment to national healing, reconciliation, justice and peace. The ZCBC (2009:6) confirms that the 'Ndebele are wounded and they do not feel that they have enough solidarity from fellow Zimbabweans even as they struggle with regional development challenges'.

Quite characteristically in the way things are performed, Mabhena (2014:1) refers to the situation in Matabeleland region as politics of revenge. Campbell (2003:115) buttresses this point with a suggestion that these divisions manifest themselves, among other things, in a lack of development projects in Matabeleland - projects that involve and are spearheaded by the locals themselves to remove the notion of 'internal colonialism'.

The Unity Accord had finally brought an end to the Gukurahundi operations but ignored the raw and festering 
wound caused by the horror of violence. Meldrum (2004:65) observes that although ' $[t]$ he grieving Ndebele resumed a semblance of ordinary life, but a huge, raw wound cut across the entire region'. Yet, as part of the package of that unity, the so-called dissidents were amnestied, while Gukurahundi was granted immunity.

Although there remained isolated incidences of violence that spilled to 1988 , they finally ceased completely.

Ultimately, the people of Matabeleland and parts of Midlands heaved a sigh of relief and a modicum of peace returned. At best the pact did not go beyond rectifying the political standoff between leaders, and hence the people's suffering and pain did not end. Thus, the much acclaimed Unity Accord fell short of addressing the victim survivors, who to this day continue to be burdened by traumatic experiences of the Gukurahundi era.

More than that, the violence was accompanied by devastating political, cultural and economic impacts. There has not been any meaningful redress to imbalances created by that violent era that destroyed people's livelihood. As a result, there is an outcry in Matabeleland against the government's lack of development initiatives. Feelings of being deliberately marginalised and dominated are rife. The inescapable truth arising from such feelings is that they have encouraged a rift between Matabeleland and Mashonaland.

Relationships are fractured and there exists a need for healing, reconciliation, justice, equity, unity and peace. In fact, the Catholic bishops have acknowledged the unique challenges that plague Matabeleland as a sign of their sensitivity to the reality. Of course, they have placed these challenges in the context of the whole country now under the regime of socio-economic doldrums. Of particular concern are the unhealed differences emanating from a historical legacy of violence. Hence, the bishops have articulated their vision of 'National Healing and Reconciliation as a home-grown inclusive that will lay foundations for a peaceful and cohesive Zimbabwean society' (ZCBC 2009:11). As part of a complementary process to this broader perspective 'envisioned' by the Catholic bishops, the Church's pastoral role of care is an important dimension for consideration. John Paul II (1988) explains how the Church sees its role:

$[T]$ he Church does not propose economic and political systems or programmes, nor does she show preference for one or the other, provided that human dignity is properly respected and promoted, and provided she herself is allowed the room she needs to exercise her ministry in the world. (p. 41)

Since the first social encyclical, Rerum novarum in 1891, the Roman Catholic Church has remained resolute in its concern for social issues, especially those that infringe on the wellbeing of humanity. The Second Vatican Council expanded on this. The Pastoral Constitution, Gaudium et spes (1966:9), introduced by Angelo Scola, expressed the Church's commitment to 'finding solutions to the problems of our time'. Paul VI in his encyclical, Populorum progressio (1990:12), expresses the aim of the Church, namely, to 'foster the human progress of the nations to which she brings faith in Christ'. The region of Matabeleland is a compelling case. Yet, in the eastern region of Mashonaland, there has been reasonable development. According to the ecumenical document, Zimbabwe Catholic Bishops Conference (2009:5), 'for the first fifteen years of post-independence, Zimbabwe made tremendous strides in almost all spheres of life'. This view does not take into account the atrocities, accompanied by socio-cultural and economic plunder, perpetrated in Matabeleland. The question of Matabeleland, the tragic violence that cost countless lives of people, has not been answered. 'Journalists, diplomats and academics [have] discussed it at length' but the answer has eluded them (Meldrum 2004:67).

It is therefore necessary to delve into this unhealed history of the region to propose the prophetic practical pastoral ministry of care as a solution, amongst others, to heal the nation. The historical involvement of the Church in human and social issues gives an impetus to this article to suggest this practical theological approach.

\section{A practical pastoral ministry of care perspective}

Given that Unity Accord did not lead to satisfaction particularly amongst the victim region of Matabeleland, it is important to employ the practical pastoral ministry of care methods as a measure of response, amongst others. The role of the Church in the given circumstances must always remain that of pastoral ministry of care. According to Bernier (2015:xviii), '[t]he church exists in history. A theology of ministry is first and foremost a study of history' and '[f]orms of ministry come from different periods of history'. This theology of practical pastoral ministry of care must be rooted in the person of Jesus incarnate. 'The affirmation that Jesus is true God and true man indicates the source of his power to save in history' (The Theological-Historical Commission for the Great Jubilee of Year 2000, 1997:20). This highlights practical pastoral ministry as adaptable, practical and caring in history and time. Thus, the phrase 'practical pastoral ministry of care' is an emphasis on the need for radical grounding of the pastoral ministry. It defines the Church's true solidarity with the human family, individually or collectively. It has played 'a critical role in the social, economic and political life of Zimbabwe for many decades' (Muchena 2004:257). What this suggests is that there are theological considerations even in the context of social, economic and political issues.

Whenever theology engages with the social context, concepts such as justice, love and mercy come into play (Byrne 1988). A theological discourse in conversation with a context of injustice has to be a grounded faith as a living reality. Practical theology, as a theology of practice, of lived religion, has the task of linking faith and the existential sphere of human beings. To fulfil this task, the human sciences often provide 
useful methods for social analysis. Dillen and Mager (2014) describe it as follows:

Practical theology seeks to hold different poles together: theory and practice, tradition and experience, reality and ideal, description and prescription, written text and text of life, theology and other disciplines, religious community and society. (p. 301)

Practical theology is therefore a discipline that combines religion and life, faith and human reality. It is a thought-out approach that seeks dialogue before action - that knocks before it opens the door. The reality has the first voice and a practical theologian is disposed to its sound. It means being present and attentive so as to appropriate relevant response. In essence, it presents itself as both a model and method of engagement. It empowers in the most practical way pastoral ministry of care. With regard to the action required in any situation of need, Pope Francis (2013) articulates the challenge as follows:

Our goal is not to amass information or to satisfy curiosity, but rather to become painfully aware, to dare to turn what is happening to the world into our own personal suffering and thus to discover what each of us can do about it. (p. 17)

In brief, even as practical theology research is undertaken and the findings reflected upon, it does not stop with that. There must be methods of application in the actual field of pastoral ministry of care. From this perspective, the goal is to ground Christian faith in the reality of human suffering through committed theological reflection. Kinast (2007:873) describes theological reflection as 'a group process that begins with an actual, pastoral situation; correlates theological resources with their situation; aims at an informed course of action, "praxis," as a result'. This correlates with the view of Pope Francis that theological theory itself is not sufficient, but should lead to a theological praxis. According to Kinast (2007:873), it is essential to realise that 'pastoral care is sought out rather than pastoral care being fit into a predetermined theological framework'. This points to the fact that pastoral ministry of care reaches out, is sensitive and flexible in its approach. The context is prioritised and there are no rules or methods of application prior to the ministry; it is grounded in the reality and determined by the same reality. This is how solidarity as articulated in the Gaudium et spes (1966) is put into practice. The aim is that human 'joy and hope, sorrow and anxiety find an echo' in the Christian community (Gaudium et spes 1966:1). Therefore, the social involvement of the Church is not a political ideology, but is rather about the light and power of the gospel actively working in the social reality. Merrienboer (1993:176) puts it as follows: ' $[t]$ he social gospel can in no way be compared to an ideological stance because it does not offer a blue-print for a particular social or economic system'.

Faith is linked to justice and justice is linked to faith.

Applied to the actual context, reciprocity is sought in the linking of faith and justice to a concrete context and vice versa. Thus, the modus operandi of pastoral ministry of care is conversational. Basically, pastoral ministry of care is based on the very ministry of the parable told by Jesus about a shepherd who goes out to seek a lost sheep (Lk 15:4). God himself declares: 'As a shepherd seeks his flock when he finds himself among his scattered sheep, so I will tend my sheep. I will rescue them from foreign lands; I will bring them back to their own country ...' (Ez 34:12). Above all, pastoral ministry of care is inspired by Christ's teaching particularly on the love of neighbour which is derived from the love of God for all of God's creation. This love of neighbour is motivated by the principle of the imago Deithat humans are created in God's own image and so deserve to be treated and respected accordingly. The Congregation of the Clergy (1997) articulates the human dignity aspect of justice as follows:

The Church, in her analysis of the soil of the world, is acutely conscious of everything that injures the dignity of the human. She is aware that all human rights spring from this dignity, the constant object of Christian concern and commitment. (p. 18)

This consciousness, this concern and commitment are the foundation upon which Catholic social teaching is built. An important aspect of the social teaching of the Church is that it emanates from the concrete circumstances of human existence. Love (2015:159) argues that, as such, the Church 'does not stand on the side lines where sovereign states are unable or unwilling to protect human life and dignity and the common good'. Yet, while governments enjoy autonomy, they have to be taken to task when in breach of principles of common interest. In this case, the prophetic role is pertinent in challenging sovereign states to exercise their power with care and with limits. According to Callahan (2015:130-131), these 'limits also concern ends or purposes: governments must promote justice and the common good'.

Essentially, the Church through her social teaching has the overall sight on the dignity, welfare and safety of all of human race in focus. Wolfteich (2014:331) points to the tradition of Catholic social teaching and socials action in which examples of practical theology can be identified and studied. The social teaching of the Church is a practical and theological way of dealing with social issues. Kasper (2013:186) traces this particular kind of involvement of the church back to 'the emergence of social problems and scandalous injustices, caused by industrial revolution in the nineteenth century'. Since that time the Catholic Church has been developing its social teaching. The Church, from a universal perspective, identifies social challenges that are a hindrance to human progress and development and confronts them. Conclusively through its social teaching and its application, it has a developed socio-pastoral ministry of care for those who suffer the pain of injustice. According to Gaudium et spes (1966:8), it is people's 'business to establish a more serviceable political, social and economic order, an order more helpful to individuals and groups in vindicating and maintaining their dignity'. Unless people and particularly Christians have a developed sense of their Christian faith, its moral and social 
implications, the task to 'establish serviceable' conditions becomes almost impossible. Such obligations require a sense of commitment and dedication in every context of human rights abuses. They truly express the Church's concern for the realisation of a just social order in which love, peace and human progress are achievable. This concern should not only be viewed and understood from a purely mundane perspective but must also be seen as a quest for a practical theological reflection about contexts of injustice. The end result of such a reflection is an informed pastoral ministry of care.

The felt sense of human suffering and pain invokes the Church's response. Pope John Paul II (1988:6) puts it as follows: ' $[b]$ efore this vast panorama of pain and suffering the council wished to suggest horizons of joy and hope'. While the papal encyclicals deal with global issues, the bishops' conferences issue pastoral statements in local contexts as a method of pastoral response to situations that threaten justice, peace and the development and progress of peoples. These constitute the Church's practical response to social challenges. Bastianel (2010:23) puts it as follows:

The intervention of the ecclesiastical Magisterium in the social sphere is always driven by real-life problems, where at issue are values, human rights and duties, with problems and positive possibilities affirmed or contradicted, due to cultures of relationships and economic, social and political structures in differentiated historical circumstances. (p. 23)

This 'intervention' of the Church in the social sphere reflects its commitment to social engagement. In a sense, the Church's body of literature on its social teaching is an important resource in the field of practical pastoral ministry of care.

In an attempt to address the question of Matabeleland, there is a realisation that the issues are rather complicated, yet in the interest of the common good, solidarity, equality, justice and peace, they must be addressed. The lack of meaningful development in Matabeleland evidently speaks about marginalisation. Such development, however, is denied by the Zimbabwean government. For the Church since the Second Vatican Council, there has been 'an increasing awareness that living out this gospel value must include changing the situations which create poverty and injustice' (Merrienboer 1993:181). Pope John XXIII, in his encyclical, Mater et magistra (1961), emphasises that 'the State, whose purpose is the realization of the common good in the temporal order, can by no means disregard the economic activity of its citizens'. It is my contention that when such 'disregard' has occurred, the need is for special advocacy and the principle of subsidiarity to be applied. According to Cavanaugh (2015:97), this principle 'states that social problems should be addressed at the lowest level at which they can be addressed effectively'. What is therefore needed is extensive engagement and dialogue regarding the issues. Here, the Church needs to raise its prophetic voice as a form of advocacy and also to seek to engage with the state. At the same time, the grassroots people have to be educated and encouraged in demanding their constitutional rights so that they become active in defending themselves and emancipating themselves from unjust practices of the state.
There is a need for recognition of the people of Matabeleland, who were actually leading in resisting colonialism. They kindled the spirit of nationalism, and, therefore, they deserve equal treatment in the areas of political, cultural and socio-economic progress and development. Campbell (2003:272) points out, however, that 'the levels of violence in Matabeleland between 1981 and 1983 permanently alienated a large section of the population from political leadership in Harare'. It is here that programmes to promote reconciliation at national level should be considered as ideal. In this case, the Church could play a pivotal role in helping creating platforms of dialogue between the people of Matabeleland and the state. This would be in a way to seek the reintegration of the region into the nation. The major bone of contention is the political and socio-economic injustice and inequality with regard to the distribution of economic goods. It is in such circumstances that Schindler (2015) sees the place of theology:

Recovery of the place of metaphysics and theology, especially in their integrative capacities in the realization of wisdom and as themselves integrated by love, 'is indispensable if we are to succeed in adequately weighing all the elements involved in the question of development and in the solution of socio-economic problems.' (Caritas Veritate [CV], no. 31) (p. 80)

To apply such a reflection to the context of Matabeleland requires a strong commitment to justice.

According to Polan (2005), we see:

$[I] \mathrm{n}$ the Bible, the covenant relationship that the people have with God is the basis of the responsibility of justice that they have towards each other. Human justice is a mirror of divine justice. (p. 510)

The Church's ministry should focus on the needs of the poor and the oppressed and through its various platforms raise the awareness on the plight of the poor and oppressed. This category of people further needs to be empowered through educative programmes so that it can learn to harness its own potential and energy in soliciting and affirming its own rights and responsibilities. In light of the gospels, Merrienboer (1993:179) points out that 'God's care extends to even the birds and flowers, indeed all creation, but is even greater for humanity'. The message of God's loving care must be part of pastoral preaching which is in essence an aspect of ministry of care because humans do not 'live by bread alone but by every word that comes forth from the mouth of God' (Mt 4:4). Harrill (2005:515) also points out that 'from the early Jesus movement, some early Christian preaching taught concern for the less fortunate in society', the poor and the marginalised. The Church in its evangelisation must seek to revive and rejuvenate the spirit of prophetic preaching, the preaching that challenges the status quo and seek alleviation of the people's suffering.

Inequality in terms of development can be a serious source of conflict and get in the way of peace and reconciliation. According to Launderville (2005:709), the view is that in 
conflict situations, the well-being (shalom) of an individual or of one group or nation is perceived to be at odds with the well-being of another'. The reason for raising this question of political, cultural and socio-economic injustice in Matabeleland is not only to offer technical solutions but also to advocate for justice, peace and reconciliation.

According to Bennet (2006), the understanding is that:

[A]ll people have a right to participate in the economic, political, and cultural life of their nation. It is wrong for any person, group, or political elite to unfairly exclude others from participating in matters that affect their lives. (p. 71)

Generally, the people of the south western region have been denied full participation. Should they be emancipated, their political, cultural and socio-economic situation could improve. This can then lead to solidarity and peace. The principles of solidarity, subsidiarity and common good are realistic and applicable in the context. In this order, these principles can galvanise the aspects of re-integrating Matabeleland as part of Zimbabwe that they find fellowship with the rest of the country, that they can be empowered through subsidiarity to take up the responsibility of their own development within the context of what is good not only for them alone but also for the whole country. The CSDC (2004) describes the relationship between solidarity and economic well-being as follows:

The relationship existing between the family and economic life is particularly significant ... The family, therefore, must rightly be seen as an essential agent of economic life, guided not by the market mentality but by the logic of sharing and solidarity among generations. (p. 248)

The exclusion of any group from the mainstream of politics and socio-economic development has dire implications for families. Many post-colonial governments have maintained colonial systems that deprive local communities, based on their tribal bias. Minority groups in different regions of certain countries are more often denied access to benefits from their own local resources, employment and education opportunities. Consequently, even development projects that arise within the minority communities are usually supervised by the powerful majority groups coming from outside the region, raising the supremacist and superior notions reminiscent of white colonial masters over black people. Everything must be motivated by the fact that 'we are equal in dignity, for we are all created in the image of God' (Diat 2015:180), or even more in the image of the trinitarian God in which we are able to relate with each other and live in harmony. However, the 'majority ethnic supremacist' tendency usually projecting themselves as the new masters of post-colonial Africa results in conflict becoming inevitable as the local community may be compelled to resist. In such cases, as a tool to silence their resistance, they are labelled as being tribal, yet in reality, the truth lies elsewhere somewhere where no one likes to look. Government positions are taken up by the majority ethnic groups. In such cases, there is no equality or subsidiarity. Himes (2013) explains the principle of subsidiarity as follows:
Subsidiarity maintains that the state's role is to help these smaller communities achieve their proper aim whenever they are unable (or unwilling) to make their distinct contribution to the overall well-being of the person or the larger community. (p. 212)

This principle gives precedence to local management of resources, employment, health and educational opportunities for the benefit of the locals. In a nutshell, local people manage their economy. Hence, when the central government fails to recognise this, it loots resources and prevents local people from gaining access to education and employment opportunities; it operates in a similar way as colonial regimes. In this respect, in the spirit of creating harmony, according to the CSDC (2004), subsidiarity relates to:

$[R]$ espect and effective promotion of the human person ... safeguarding human rights and the rights of minorities ... making citizens more responsible in actively 'being a part' of the political and social reality of their country. (p. 187)

Ultimately, the effect of such a practice is participation and sense of solidarity. It is important to consider the words of Francis (2013:59), which read as follows:

But until exclusion and inequality in society and between peoples is reversed, it will be impossible to eliminate violence. The poor and the poorer peoples are accused of violence, yet without equal opportunities the different forms of aggression and conflict will find a fertile terrain for growth and eventually explode. (p. 59)

The rise of various pressure groups and political organisations in Matabeleland that have in the recent past led to temporary closure of certain companies on the basis of imported labour and the call for secession are pointers that people's patience is running out.

Occasions of violence leading to the arrest of the activists have been witnessed in the recent past although the state media does not report on these. The ZCBC (2011:4) has written sentiments that continue to echo in hearts of those oppressed by economic hardships: '[ $t$ o fight misery and to struggle against injustice is to promote the human and spiritual progress of all people, therefore, the common good of humanity'. The nature of such pastoral letters is that they emanate from the daily experiences of people's lives, and therefore, they are a true reflection and practical expression of what the people are going through. According to the CSDC (2004:189), participation entails that citizens individually or collectively 'whether directly or through representation, contribute to the cultural, economic, political and social life of the civil community to which he/she belongs'. Such practice could lead to greater unity in the country and foster a common vision of the common good.

The Church in practical theological conversation cannot ignore the anthropological dimension of the matter.

A practical pastoral ministry of care has a holistic approach to human beings. According to Kanyandogo (2001:117), 
theologising should address 'the conditions for the promotion of humanity in its historical, material and cultural aspects'. This, in turn, serves justice and peace. Pope Benedict XVI in his apostolic exhortation, Africae munus (2011:2), foresaw that this would 'rekindle our faith and hope, so as to help build a reconciled Africa by pursuing the paths of truth and justice, love and peace' (cf. Ps 85:11). This is a much needed activity of the Church in the context of Zimbabwe, and also elsewhere in the world where similar conditions of injustice prevail. Wadell (2005:519) suggests that justice is not only a cardinal virtue, but is also $[a]$ "constitutive dimension of the preaching of the Gospel" by structuring a world that keeps us from being one'. Thus, promoting equal participation in the sphere of political, cultural and socio-economic development enhances the prospect of peace and harmony. Justice is impossible unless all men and women are equally regarded as brothers and sisters, not outsiders or strangers but members of the family of God (Wadell 2005:517). This impels the conversation to consider the most elementary aspect of evangelisation.

Evangelisation is not only the preserve of the ministers of religion but it is also the responsibility of all the baptised and the faithful of Christ. Hence, the pastoral task of the Church is not left to pastors and Church officials.

The aim is a lived faith that is shared by all members of the faith communities. In the context of a political and socioeconomic crisis, the tradition of the Catholic bishops in Zimbabwe is to write a pastoral letter which is then distributed and read in all missions and parishes and further given to the individual faithful. As such even non-Catholics find access to it. There is no doubt that these pastoral letters, because of their relevance and their clear articulation of national issues, have a practical influence on the people. It is only then that the Church, corporately through its faithful followers, can become an effective instrument of grace and source of hope. People in their local communities are encouraged to be able to stand up and articulate their challenges and reject being subdued and undermined as if they are not aware of their rights. This encouragement can be a part of deliberate missioning of the Church in Matabeleland. Faith lived in love and justice can contribute to the positive development of all people. According to Pope Benedict XVI (2009:1) in his encyclical, Caritas in Veritate, charity and truth are the principal driving force behind the authentic development of every person and all of humanity'. These values must not only be known, but should also be pronounced and applied in the actual life of people and in their daily experiences.

The challenge to bring about integral transformation that focuses on justice, development and peace is particularly great in southern Africa (Luna 2005:49). This includes the context of Zimbabwe, which is, given the circumstances, prevailing particularly in the south western region, in need of a prophetic practical pastoral ministry of care as an alternative to what is going on at present. As already pointed out, the Catholic bishops have stated: '[w]e envision National Healing and Reconciliation as a home grown inclusive process that will lay the foundations for a peaceful and cohesive Zimbabwean society' (ZCBC 2009:11). This broad-based vision and approach require a programme in which all can participate. The Church should also come up with its own strategies and methods based on a pastoral ministry of care to complement such joint programmes that could also be initiated in other sections of society. It speaks about truth (ZCBC 2011):

$[M]$ any of you, who have endured much, are beginning to show signs of losing hope as the political, economic and social hardships, which should have disappeared by now, still persist. (p. 9)

Although this addresses the general situation in the country, there is no reason to believe that these words have a unique and applicable meaning to the people of Matabeleland. They have in a special way 'endured much' and there are 'signs of losing hope' in a practical sense. Many have, since the political mayhem of the 1980s, lived in diaspora on political asylum and as economic refugees. Their families are disintegrated without hope of reunion. Mills (2007:836) understands pastoral care broadly as care for society and communities, as well as for individuals and families who seek spiritual guidance. Thus, the ministry of care should be broader and encompass ministering to broken families. Such a broad kind of engagement is needed in the context that is being investigated.

Ample evidence has been provided for the Roman Catholic Church's engagement with social realities as an instrument of social justice, peace, solidarity and love. This role and behaviour is motivated by a pastoral concern and the intention is to formulate effective methods of intervention. One fundamental aspect of encyclicals is their practical nature. Trisolini (2011:16) attests that 'social encyclicals are the Church's institutional response to the social problems of a given time period' referred to 'as practical or praxis theology' or even 'as strategic theology'. These documents are primordial in the social teaching of the Church which itself

[A] commitment to justice ... condemnation of evils and injustices ... part of that ministry of evangelization in the social field which is an aspect of the Church's prophetic role. (Trisolini 2011:10)

They provide an essential content in practical pastoral ministering where effective methods of intervention are required. In John Paul II (1988:41), 'we might say that Catholic social doctrine is based on an act of principles of reflection, criteria for judgement and directives for action proposed by the Church's teaching'. What is now required is to apply those practical theological reflections and adapt them to the context. This should always reflect the person of Jesus; otherwise, pastoral care will not adequately and authentically serve its purpose. The incarnational model is identified as appropriate to this particular problem. At the heart of any pastoral action is the person of Jesus Christ, the model of pastoring. According to Smith (1995:xi), 'it is the work of 
Jesus to gather everything together, and ultimately nothing is left out or behind'. This should be the spirit reflected in a pastoral ministry of care. I argue that a pastoral ministry of care is essentially about bringing the good news of the gospel to contexts that need a different perspective.

In pastoral practice, the word that became flesh should be experienced as an in-dwelling presence and reality.

This should permeate the Church's ministry to people. According to Brusatti (1993:215), 'the pastoral word or word finally spoken, concerns itself with experience, significant human experience interpreted theologically'. Thus, the preaching itself during liturgical services must be relevant to the suffering and pains of the people. It is a form of pastoral presence attuned to the reality and only then can the process of healing begin to take place. A pastoral presence is therefore necessary for pastoral reflection to be authentic.

Admittedly, bringing the good news of Christ to social contexts of injustice is a daunting task that requires meticulous planning for pastoral action. It means preaching itself as part of pastoral attendance in order to be prophetic requires attentiveness to the human experiences of suffering. Smith (1995:xi) points out that, because Jesus has gone to the father, his followers are the ones who will continue his work and do works even greater than his. Their words and actions should be like his: have an enduring power and bear fruit.

Changing contexts require an openness of heart and mind in order to remain relevant. In the act of preaching, the spiritual and human stories are synthesised through language to create new meaning. Imaginative language invites participation and listening to 'the word more deeply' (Brusatti 1993:215). Therefore, a pastoral ministry of care must be holistic and create conditions for active participation. According to Bernier (2015:310), 'the word the presbyter preaches is not simply consoling; it is meant to be challenging and prophetic' because it interfaces with Christ's own prophetic living. An authentic encounter with the incarnate Jesus Christ has the power to transform lives. Faith should manifest in life, action, praxis and ethical life (Pathil \& Veliath 2005:43). In order to aid Christians to witness to their life in Christ and become relevant to the communities they are part in terms of experiences of suffering, the Church leadership must provide programmes of action geared towards empowering survivor victims of political violence. Hence, pastoral practice aims to illumine lives and enliven people, to instil in them a sense of hope even in the circumstances where everything seems gloomy. 'Christian belief ought to see suffering as a consequence of sin and, at the same time, evaluate it in the light of the resurrection of Jesus' (Magnante 1997:131). The ultimate end in presenting Christian faith is hope as the inevitable irrespective of the daring challenges of life. This defines again the ultimate goal and end of pastoral ministry of care.

Jesus Christ's own person and work draws our attention to God's presence and saving power. God is potentially present in all that he created and in all people who are made in God's image. Jesus Christ's own practices provide insights for designing practical pastoral care model and methods in present-day contexts. Paul VI (1967) states:

[T]his is the sublime mystery of the incarnation of the word of God, which took place in history: in clearly defined circumstances of time and space, amidst a people with its own culture. (p. 60)

Hence, Jesus' own ministry of care was adaptable and strategic in response to the circumstances, time and culture. It was an inculturated ministry attentive to the needs of time. Bevans (2014:264) points out the inclusive characteristic of Jesus' ministry which revolved around the marginalised and sinful people of his time. To some extent, one could argue that the victim (the marginalised) and the offender (the powerful) are taken into account equally. God is the one who takes the first step in the reconciliation of victim and perpetrator. God opens the heart of the victim to the possibility of forgiveness (Bevan 2014:267). It is critically important if healing has to occur that the victims take an initiative towards their own well-being. Parker (2001) attests that:

[F]rom the death of Jesus that he was abused physically and tormented by cruel words and abandoned like [the victims] but ... in response to abuse he offered forgiveness and his resurrection declared that God [had] free[d] him from the effects of his suffering on the cross. (p. 43)

Victimhood is anchored in the feeling of alienation and those who alienate if they lack remorse may see no cause for reconciliation or asking for pardon. Hence, even if they would want to reconcile with their victims that cannot be achieved without the offended first being free to forgive, 'yet it is very difficult to forgive while the heart is full of pain' (LIoyd \& Bresser 2001:27). However, through educative workshops, rituals of healing the people of Matabeleland can find healing, the nation can be healed. 'The liturgy embodies and enacts the healing touch of the divine transcendence, surrounding life with meaning and giving it hope' (Veith 1988:132). Thus, liturgy is a powerful practical pastoral ministry of care which brings healing. The Church through such liturgies is able to relate itself to the situation of the survivors of political violence.

The Truth and Reconciliation Commission (TRC) of South Africa provides an important model adaptable to practical pastoral ministry of care. It has a powerful emphasis on forgiveness, healing and reconciliation.

Tutu (1999:82) points out, '[i]t meant that theological and religious insights and perspectives would inform much of what we did and how we did it'. This suggests that methods of application even in the context under review could adopt some elements from that process. These methods could take various forms, such as workshops, storytelling, memorialisation, and healing services and memorial services. The concept of Cross Workshop used in Rwanda could also be ideal (LIoyd \& Bresser 2001:40, see Parker 2001:72). Renowned Catholic theologian Schillebeeckx (1990:88-89) sees how, in 
the passion and death of the incarnate Christ, 'vulnerability and defencelessness are more capable of powerfully disarming evil than the brute force in the world could ever accomplish'. The incarnational model takes its guidelines from the concrete ministry of Jesus who, in his humanity, encountered the real world and the social contexts of injustice that in his day were rather similar to what marginalised human beings still experience today. Jesus incarnate identified with his people's history 'yet he permanently condemned some practices such as idolatry, ethnocentrism, hypocrisy, racial differences, and many other prescriptions, which kept persons in a cultural ghetto' (Paul VI 1967:21). His practical ministry was to reconcile people with God and with one another. $\mathrm{He}$ challenged everything that was an obstacle to harmony, justice and peace. Healing and reconciliation was the core of his ministry and, indeed, all directed at the kingdom of God. In this sense, the context of Matabeleland cannot be exceptional but can be redeemed through well-planned pastoral ministry of care. Yet, to the people of Matabeleland, it must be crystal clear that (Jankelevitch 2005):

$[W]$ hen a crime can neither be justified, nor explained ... when the atrocity has neither mitigating circumstances, nor excuses of any sort ... then there is no longer anything else to do but forgive. (p. 106)

It is conclusive that forgiveness itself constitutes healing although the memory of what happened can never be obliterated. The burden of trauma is relieved and the survivors can see the possibility of starting afresh in life.

\section{Conclusion}

This article has explored the challenges faced by the people of Matabeleland who bear the brunt of political violence that affected their cultural and socio-economic growth. It provides a critical historical overview pointing out in brief the source of the suffering pain. There are points in which history is seen as a major culprit that continues to hold people into hostage of past events. However, the Roman Catholic Church has been present in all the events giving its practical aid and taking side with those affected by the war of liberation. Even as the events of the massacres of the 1980s unfolded, the Church kept its watchful eye.

Many times, it issued statements to encourage reconciliation, without, however, failing to give a warning on the dire consequences if reconciliation policy is not adhered to with commitment. The 1980s massacres highlighted a serious rupture of a post-colonial Zimbabwe with need for healing from a prophetic practical pastoral ministry of care perspective. This proposed role is taking Jesus incarnate as a model and example in the field of practical pastoral ministry of care. Jesus is viewed as a historical personage who can heal or save human history from debilitating effects. There are methods suggested for application, such as workshops, para-liturgical services as seen in the processes of the TRC, memorialisation and healing services. These are envisaged as methods that effect healing and relieve survivors of the trauma they have borne for decades now.

\section{Acknowledgements Competing interests}

The authors have declared that no competing interest exists.

\section{Authors' contributions}

All authors contributed equally to this work.

\section{Ethical consideration}

This article followed all ethical standards for a research without direct contact with human or animal subjects.

\section{Funding information}

This research received no specific grant from any funding agency in the public, commercial or not-for-profit sectors.

\section{Data availability statement}

Data sharing is not applicable to this article as no new data were created or analysed in this study.

\section{Disclaimer}

The views and opinions expressed in this article are those of the authors and do not necessarily reflect the official policy or position of any affiliated agency of the authors.

\section{References}

Alexander, J., McGregor, J. \& Ranger, T., 2000, Violence and memory: One hundred years in the dark forests of Matabeleland, Weave Press, Harare.

Bastianel, S., 2010, Morality in social life, Convivium Press, Miami, FL.

Benedict XVI, 2009, Caritas in veritate, Libreria Editrice Vaticana, Vatican.

Benedict XVI, 2011, Africae munus: Apostolic exhortation on the Church in Africa in service to reconciliation, justice and peace, Word Media-svd, Benin.

Bennet, M., 2006, Faith and social justice, Paulines Publications Africa, Nairobi.

Bernier, P. 2015, Ministry in the church: A historical and pastoral approach, Orbis Books, Maryknoll, New York.

Bevans, S., 2014, 'Missiology as practical theology: Understanding and embodying mission as trinitarian practice', in C.E. Wolfteich (ed.), Invitation to practical theology: Catholic voices and visions, pp. 253-274, Paulist Press, New York.

Bhandar, B., 2007, 'Spatialising history and opening time: Resisting the reproduction of the proper subject', in S. Veitch (ed.), Law and politics of reconciliation, pp. 93-110, Ashgat Publishing, New York.

Brusatti, L.T., 1993, 'The primordial word: Preaching, poetry, and pastoral presence', in C. Bouchard, T. Brodie, L. Brusatti \& H. Byren (eds.), In the company of preachers, pp. 210-226, Liturgical Press, Collegeville, MN.

Byrne, T., 1988, Working for justice \& peace: Practical guide, Mission Press, Ndola.

Callahan, P., 2015, 'Global order in Catholic social teaching from Benedict XV to Benedict XVI', in P.J. Casarella (ed.), Jesus Christ: The new face of social progress, pp. 137-126, Eerdmans, Mahwah, NJ.

Campbell, H., 2003, Reclaiming Zimbabwe: The exhaustion of the patriarchal model of liberation, New Africa Books (Pvt) Ltd., Claremont, CA.

Cavanaugh, W., 2015, 'Dispersed political authority: Subsidiarity and globalization in Caritas in veritate', in P.J. Casarella (ed.), Jesus Christ: The new face of social progress, Eerdmans, Mahwah, NJ.

Coltart, D., 2016, The struggle continues: 50 years of tyranny in Zimbabwe, ABC Press, Cape Town.

Davis, J.F., 2013, Mission accomplished: Dr. Davis' life work in Zimbabwe, St Joseph's Mission, Hwange.

Diat, N., 2015, Robert Cardinal Sarah, God or nothing: A conversation of faith with Nicolas Diat, Ignatius Press, San Francisco, CA.

Dillen, A. \& Mager, R., 2014, 'Research in practical theology: Methods, methodology, and normativity', in C.E. Wolfteich (ed.), Invitation to practical theology: Catholic voices and visions, pp. 301-328, Paulist Press, New York. 
Eppel, S., 2004, 'Gukurahundi: The need for truth and reparation', in B. Raftopoulos \& T. Savage (eds.), Zimbabwe: Justice and political reconciliation, Institute for Justice and Reconciliation, Cape Town.

Francis, 2013a, The joy of the Gospel: Apostolic exhortation, Libreria Editrice Vaticana, Vaticana.

Francis, 2013b, Lumen fidei: Faith, ZCBC Publication, Harare.

Francis, 2015, Encyclical Laudato Si: On care for our common home, Libreria Editrice Vaticana, Vatican.

Godwin, P., 2006, When a crocodile eats the sun, Picador Africa, Johannesburg.

Guest, R., 2004, The shackled continent: A call to Christians to act in faith for an alternative Zimbabwe, University of Bamberg Press, Bamberg.

Harold-Barry, D. (ed.), 2004, Zimbabwe: The past is the future: Rethinking land, state and nation, Weaver Press, Harare.

Harrill, A., 2005, 'Justice from the church', in C. Stuhlmueller (ed.), The Collegeville pastoral dictionary of biblical theology, pp. 512-516, Theological Publications in India, Bangalore.

Himes, K.R., 2013, Christianity and the political order: Conflict, cooptation, and cooperation, Orbis Books, Maryknoll, New York.

Jankelevitch, V., 2005, Forgiveness, The University of Chicago Press, Chicago, IL.

John Paul II, 1988, Sollicitudo re socialis: On social concern of the church, Libreria Editrice Vaticana, Vaticana.

John Paul II, 2004, Compendium of the Social Doctrine of the Church, Libreria Editrice Vaticana, Vaticana.

John XXIII, 1961, Mater et magistra: On social progress. Libreria Editrice Vaticana, Vaticana.

Kanyandogo, P., 2001, 'Rethinking African ecclesiology challenges from people's rights and participation', in C. McGarry \& P. Ryan (eds.), Inculturating the church in Africa, pp. 95-119, Paulines Publications Africa, Nairobi.

Karlen, H., 1990, The way of the cross of a diocese, Unpublished Report, Archdiocese of Bulawayo, Bulawayo.

Kasper, W., 2013, The essence of the gospel and the key to Christian life, Paulist Press, Princeton, NJ.

Kinast, R.L., 2007, 'Pastoral theology, Roman Catholic', in R.J. Hunter (ed.), Dictionary of pastoral care and counselling, pp. 873-874, Theological Publications in India, Bangalore.

Launderville, D., 2005, 'Peace', in C. Stuhlmueller (ed.), The Collegeville pastora dictionary of biblical theology, pp. 709-711, Theological Publications in India, Bangalore.

Lloyd, R. \& Bresser, K., 2001, Healing the wounds of ethnic conflict: The role of the church in healing and reconciliation, Mercy Ministries International, Geneva.

Love, M.C., 2015, 'Institutional pluralism, global governance, and Nigerian emails: Benedict' call for truth and trust', in P.J. Casarella (ed.), Jesus Christ: The new face of social progress, pp. 152-163, Eerdmans, Mahwah, NJ.

Lubich, C. \& Pochet, M., 1985, Stars and tears: A conversation with Chiara Lubich, New City, London.

Luna, J.J., 2005, 'Pastoral circle: A strategy for justice and peace', in F. Wijsen, P. Henrio \& R. Mejia (eds.), The Pastoral circle revisited: A critical quest for truth and transformation, pp. 49-60, Orbis Books, New York.

Magnante, A., 1997, Why suffering? The mystery of suffering in the Bible, Paulines Publications Africa, Nairobi.

Manyika, E. Z., 2006, Edgar '2Boy' Zivanai Tekere: A lifetime of struggle, Sapes Books, Harare.

Mavuru, S. \& Nyanhanda-Ratsauka, K., 2008, Step ahead history: Student's Book Form 3, Longman, Bulawayo.

Maye, B., 2010, The search for justice: Trócaire: A history, Veritas, Dublin.

Meldrum, A., 2004, Where we have hope, John Murray, London.

Meredith, M., 2002, Robert Mugabe, Jonathan Ball Publishers, Jeppestown.

Meredith, M., 2005, The state of Africa: A history of the continent since independence, Simon \& Schuster, London.

Merrienboer, E.J., 1993, 'Practising social gospel', in C. Bouchard et al. (eds.) In company of preachers, pp. 76-90, Aquinas Institute of Theology Faculty, Liturgical Press, Collegeville, MN.

Mills, L.O., 2007, 'Pastoral theology, graduation', in R.J. Hunter (ed.), Dictionary of pastoral care and counselling, pp. 865-867, Theological Publications in India, Bangalore.

Moyo, F. \& Mabhena, C., 2014, 'Harnessing mineral resources in Gwanda District of Zimbabwe: A myth or a reality?', International Letters of Social and Humanistic Sciences 38, 1-21. https://doi.org/10.18052/www.scipress.com/ILSHS.38.1
Muchena, D., 2004, 'The church and reconciliation: A mission impossible?', in B. Raftopoulos \& T. Savage (eds.), Zimbabwe: Injustice \& political reconciliation, Institute for Justice and Reconciliation, Cape Town.

Mukonori, S.J., 2017, Man in the middle: A memoir, Jesuit Institute of South Africa, Auckland Park.

Mutanda, F.C., 1984, 'Foreword', in J. Nkomo (ed.), The story of my life, Sapes Books, Harare.

Nkomo, F.S., 2013, Joshua Nkomo, Father Zimbabwe: The life and times of an African legend, Radiant Publishing for Transformation, Harare.

Nkomo, J., 1984, The story of my life, Sapes, Harare.

Oates, W.E., 2007, Dictionary of Pastoral Care and Counselling, Theological Publications in India, Bangalore.

Parker, R., 2001, Healing wounded history: Reconciling people and healing places, Darton, Longman \& Todd, London.

Pathil, K. \& Veliath, D., 2005, An introduction to theology, Theological Publications in India, Bangalore.

Paul VI, 1990, Encyclical Populorum progressio, Libreria Editrice Vaticana, Vatican.

Paul VI, 1966, Gaudium et spes: Pastoral Constitution on the Church in the Modern World, Libereria Editice Vaticana, Vatican.

Paul VI, 1967, Populorum Progressio: On development of peoples, Libreria Editrice Vaticana, Vaticana.

Polan, G.J., 2005, 'Justice', in C. Stuhlmueller (ed.), The Collegeville pastoral dictionary of biblical theology, pp. 510-512, Theological Publications in India, Bangalore.

Raftopoulos, B., 2004, 'Unreconciled differences: The limits of reconciliation in Zimbabwe', in B. Raftopoulos \& T. Savage (eds.), Zimbabwe: Justice \& political reconciliation, pp. viii-xxii, Institute for Justice and Reconciliation, Cape Town.

Roman Catholic Bishops of Zimbabwe, 1982, Pastoral statement: Our way forward, 28 November 1982, Harare.

Sachikonye, L., 2011, When a state turns on its citizens: Institutionalized violence and political culture, Jacana Media, Sunnyside.

Schillebeeckx, E, 1990, Church: The human story of God, transl J. Bowden, Crossroad, New York.

Schindler, D.L., 2015, 'The anthropological vision of Caritas Veritate and its implications for economic and cultural life today', in P.J. Casarella (ed.), Jesus Christ: The new face of social progress, Eerdmans, Mahwah, NJ.

Smith, M.L., 1995, Nativities and passions: Words for transformation, Cowley Publications, Boston, MA

The Congregation of the Clergy, 1997, The Directory for Catechesis, Libreria Editrice Vaticana, Vaticana.

Todd, J.G., 2007, Through the darkness: A life in Zimbabwe, Zebra Press, Cape Town. Trisolini, J., 2011, Catholic social teaching, Catholic Publishing House, Seoul. Tutu, D., 1999, No future without forgiveness, Image Doubleday, New York. Veith, R., 1988, Holy power human pain, Meyer-Stone Books, Bloomington, IN.

Villa-Vicencio, C., 2004, 'Foreword', in B. Raftopoulos \& T. Savage (eds.), Zimbabwe: Injustice and political reconciliation, pp. $\mathrm{v}-\mathrm{vi}$, Institute for Justice and Reconciliation, Rondebosch, Cape Town.

Volf, M., 2001, 'Forgiveness, reconciliation \& justice: A Christian contribution to a more peaceful social environment', in R.G. Helmick \& R.L. Petersen (eds.), Forgiveness and reconciliation: Religion, public policy, and conflict transformation, Templeton Foundation Press, Radnor, PA.

Wadell, P., 2005, 'Justice', in C. Stuhlmueller (ed.), The Collegeville pastoral dictionary of biblical theology, pp. 512-520, Theological Publications in India, Bangalore.

Wolfteich, C.E. (ed.), 2014, 'Catholic voices and visions in practical theology: Contributions and future directions', in C.E. Wolfteich (ed.), Invitation to practical theology: Catholic voices and visions, pp. 329-344, Paulist Press, New York.

Zimbabwe Catholic Bishop's Conference, 2009, Pastoral letter on national healing and reconciliation: God can heal the wounds of the afflicted, The ZCBC Social Communication Department, Harare.

Zimbabwe Catholic Bishops Conference, The Evangelical Fellowship of Zimbabwe and The Zimbabwe Council of Churches, 2009, The Zimbabwe we want: Towards a national vision for Zimbabwe, A discussion document.

Zimbabwe Catholic Bishops Conference, 2009, 'Communiqué: The Zimbabwe we want - taking the process forward', Africa Synod House, Harare.

Zimbabwe Catholic Bishops' Conference, 2011, A pastoral letter: Let us work for the common good: Let us save our nation, The ZCBC Social Communication Department, Harare. 